\title{
Identification and Assessment of Livestock Best Management Practices (BMPs) Using the REDD+ Approach in the Ecuadorian Amazon
}

\author{
Bolier Torres ${ }^{1,2,3, *(D)}$, David Eche ${ }^{4}$, Yenny Torres ${ }^{5}$, Carlos Bravo ${ }^{6}$, Christian Velasco ${ }^{3,7}$ and Antón García ${ }^{2}$ (D) \\ 1 Facultad de Ciencias de la Vida, Universidad Estatal Amazónica (UEA), Pastaza 160101, Ecuador \\ 2 Department of Animal Production, Faculty of Veterinary Sciences, University of Cordoba, \\ 14071 Córdoba, Spain; pa1gamaa@uco.es \\ 3 Corporación para el Desarrollo Sostenible, Conservación y Cambio Climático (DSC), Tena 150150, Ecuador \\ 4 Universidad Regional Amazónica Ikiam, vía Tena-Muyuna Km 7, Tena 150150, Ecuador; \\ echedenriq@yahoo.es \\ 5 Department of Animal Production, Quevedo State Technical University, Av. Quito km, 11/2 vía a Santo \\ Domingo de los Tsáchilas, Quevedo 120501, Ecuador; ytorres@uteq.edu.ec \\ 6 Facultad de Ciencia de la Tierra, Universidad Estatal Amazónica, Pastaza 160101, Ecuador: \\ cbravo@uea.edu.ec \\ 7 Especialista Forestal, FAO-PROAmazonía, Quito 170518, Ecuador; Christian.VelascoRuano@fao.org \\ * Correspondence: btorres@uea.edu.ec
}

Citation: Torres, B.; Eche, D.; Torres, Y.; Bravo, C.; Velasco, C.; García, A. Identification and Assessment of Livestock Best Management Practices (BMPs) Using the REDD+ Approach in the Ecuadorian Amazon. Agronomy 2021, 11, 1336. https://doi.org/ 10.3390/agronomy11071336

Academic Editor: David W. Archer

Received: 26 May 2021

Accepted: 26 June 2021

Published: 30 June 2021

Publisher's Note: MDPI stays neutral with regard to jurisdictional claims in published maps and institutional affiliations.

Copyright: ( $\odot 2021$ by the authors Licensee MDPI, Basel, Switzerland. This article is an open access article distributed under the terms and conditions of the Creative Commons Attribution (CC BY) license (https:// creativecommons.org/licenses/by/ $4.0 /)$.

\begin{abstract}
Deforestation is a severe threat to diversity in the Ecuadorian Amazon Region (EAR). To mitigate deforestation, it is necessary to know the relevant stakeholders' roles and interactions and deepen our knowledge of the local livelihoods, objectives, potentials, limitations, and "rights of being" among farms, as well as the best management practices (BMPs). In this study, our aim was to identify and assess livestock BMPs along an elevational gradient to foster sustainable production and reduce emissions from deforestation and forest degradation (REDD+). This approach could be environmentally and economically beneficial. Data were collected from 167 households along three elevational gradients, as well as from 15 interviews held among a multidisciplinary panel of key stakeholders and researchers in the EAR. The results showed that most of the Kichwa population lives in the medium zone, which features a larger agricultural and forest surface. Conversely, in the lower and upper areas, livestock predominates, where the upper area is specialized in milk production and the lower area in dual-purpose cattle (meat and dairy). The stakeholder assessment provided several key results: (a) social, structural, and technical factors have complementary effects on BMP adoption; (b) the sixteen assessed BMPs facilitated the implementation of existing financial incentive programs and enabled public-private partnerships to develop REDD+ projects. The policy implications of implementing these approaches are also discussed.
\end{abstract}

Keywords: biosphere reserve; Ecuadorian Amazon; pasture; restoration; REDD+

\section{Introduction}

The establishment of grazing lands for livestock accounts for $77 \%$ of the total farming land in the world [1] and produces $14.5 \%$ of global greenhouse gases (GHGs) [2]. This issue is particularly prominent in the tropics, where deforestation conventionally generates pasture for cattle-raising and other basic crops [3]. Thus, the global dilemma is determining how to improve productivity in a sustainable way [4]. In terms of livestock production, an alternative could be "sustainable intensification" [5]. This option has gained substantial attention over the last few years under the global scenario of climate change. The Cancun Agreements, which resulted from the Conference of the Parties (COP 16), marked a milestone in international policy oriented to reduce emissions from deforestation and forest degradation (REDD+), thereby setting the definition of the REDD+ pillars and climate change mitigation efforts [6]. 
This research focuses on the Ecuadorian Amazon Region (EAR). In this region, the main drivers of deforestation and forest degradation are related to land-use change for agriculture and pastures [7,8], land clearing for the opening of oil and non-oil roads [9], oil and mining exploitation [8,10-12], population growth [13], and timber extraction [14,15].

The pastures for cattle-raising implemented in the EAR are extensive [16-18] and are the main causes of land-use change [7,15]. Moreover, many cattle-raising practices are not aligned with the ecological reality of this region $[19,20]$, threatening the conservation and sustainable use of Amazonian biodiversity. In 2014, about 1.2 million hectares of pastureland for cattle-raising were registered in the Ecuadorian Amazon [16], where landscape restoration actions could be promoted through the implementation of good cattle-raising practices in the context of REDD+ actions, such as technological innovation processes for managing the ecological system, the restoration of released areas, and productive reconversion.

Ecuador has carried out several efforts aimed at reducing emissions, including developing policy instruments such as the prime regulatory policies, which are at the core of the Environmental Organic Code (in the Spanish language: Código Orgánico del AmbienteCODA (Official Gazette Supplement No. 983 on 12 April 2017 came into force on 13 April 2018.)). The CODA addresses issues such as climate change, protected areas, wildlife protection, forest heritage, environmental incentives, environmental quality, waste-management, access to genetic resources, biosecurity, and the bioeconomy, among other issues [21]. Furthermore, the CODA considers Agenda for Productive Transformation in the Amazon (ATPA) approaches [16]. Through Ecuador's REDD+ Action Plan [6] and UNFCC, (UNFCCC 2008), actions to achieve reductions in deforestation, conservation, and the sustainable use of biodiversity have been developed. Actions have been carried out to avoid deforestation/degradation, improve the soil carbon stock, reduce GHG emissions, improvement of soil carbon stock, and facilitate social and environmental co-benefits.

Ecuador created the ATPA [16] as part of the solution to reduce the expansion of the agriculture frontier. The main aim of ATPA was to convert 300,000 hectares of pastureland to agroforestry, silvopastoral, and forestry-integrated mixed systems $[6,16]$. The Chakra, a traditional agroforestry system characterized by its high levels of timber content [22], fruit trees, diversity [23-25], and promotion of food sovereignty and social and cultural benefits [26,27], was also considered. Therefore, the implementation of ATPA approaches requires an understanding of both the livelihoods of local populations and the best management practices (BMPs) that could release pasture areas for restoration or the implementation of silvopastoral systems. Silvopastoral systems, or grasslands with dispersed trees, contribute to carbon sequestration $[17,28]$ and are key elements in international discussions where REDD+ strategies aim at mitigating environmental stressors. In this regard, the success of adopting BMPs in the transition to sustainable livestock production depends on appropriate knowledge of the local realities of livestock production systems [29].

Therefore, this study has a double objective: first, to characterize the farms along the elevational gradient in the upper Ecuadorian Amazon; and second, to identify and assess the best management practices (BMPs) in each ecological zone that help foster sustainable production using the REDD+ approach and environmental and economic co-benefits. The research questions were evaluated by applying a mixed methods approach, combining qualitative and quantitative methodologies. Using the quantitative methodology, according to social, structural, and technical characteristics, the farms were characterized for each altitudinal gradient of Amazonia. Later, considering the qualitative methodology with a panel of 15 experts, BMPs were selected for sustainable production using the Ecuadorian REDD+ action plan. This research was developed in the buffer and transition zone of the Sumaco Biosphere Reserve (SBR), located in the northern and central part of the EAR. 


\section{Materials and Methods}

\subsection{Study Area}

This research was carried out across an upper Amazonian hotspot [30] that is considered an important protected area, and the Sumaco Biosphere Reserve (SBR), created in 2000 by UNESCO's Man and Biosphere program (MAB), both located in the province of Napo. We worked with livestock households located from $400 \mathrm{~m}$ above sea level in the low zone to $2000 \mathrm{~m}$ above sea level in the high zone (Figure 1). In addition, the study area is located in one of the world's biodiversity hotspots (Uplands Western Amazonia) [30-32]. The predominant ecosystems were as follows: evergreen foothill forest (BsPn03) in the low zone, and low montane evergreen forest (BsBn01) and montane evergreen forest (BsMn01) in the low, medium, and high zones in the northern part of the Eastern Cordillera of the Andes [33]. The region under study presents a tropical climate with high temperatures, and is divided into three zones: a low zone with a temperature range between 22 and $24^{\circ} \mathrm{C}$, annual rainfall of $3950 \mathrm{~mm}$, and $84-87 \%$ relative humidity; a medium zone with annual rainfall of $4500 \mathrm{~mm}$, a $24{ }^{\circ} \mathrm{C}$ average temperature, and less than $80 \%$ relative humidity; and a high zone with annual rainfall greater than $2000 \mathrm{~mm}$, a temperature range between 14 and $19{ }^{\circ} \mathrm{C}$, and $88 \%$ relative humidity.

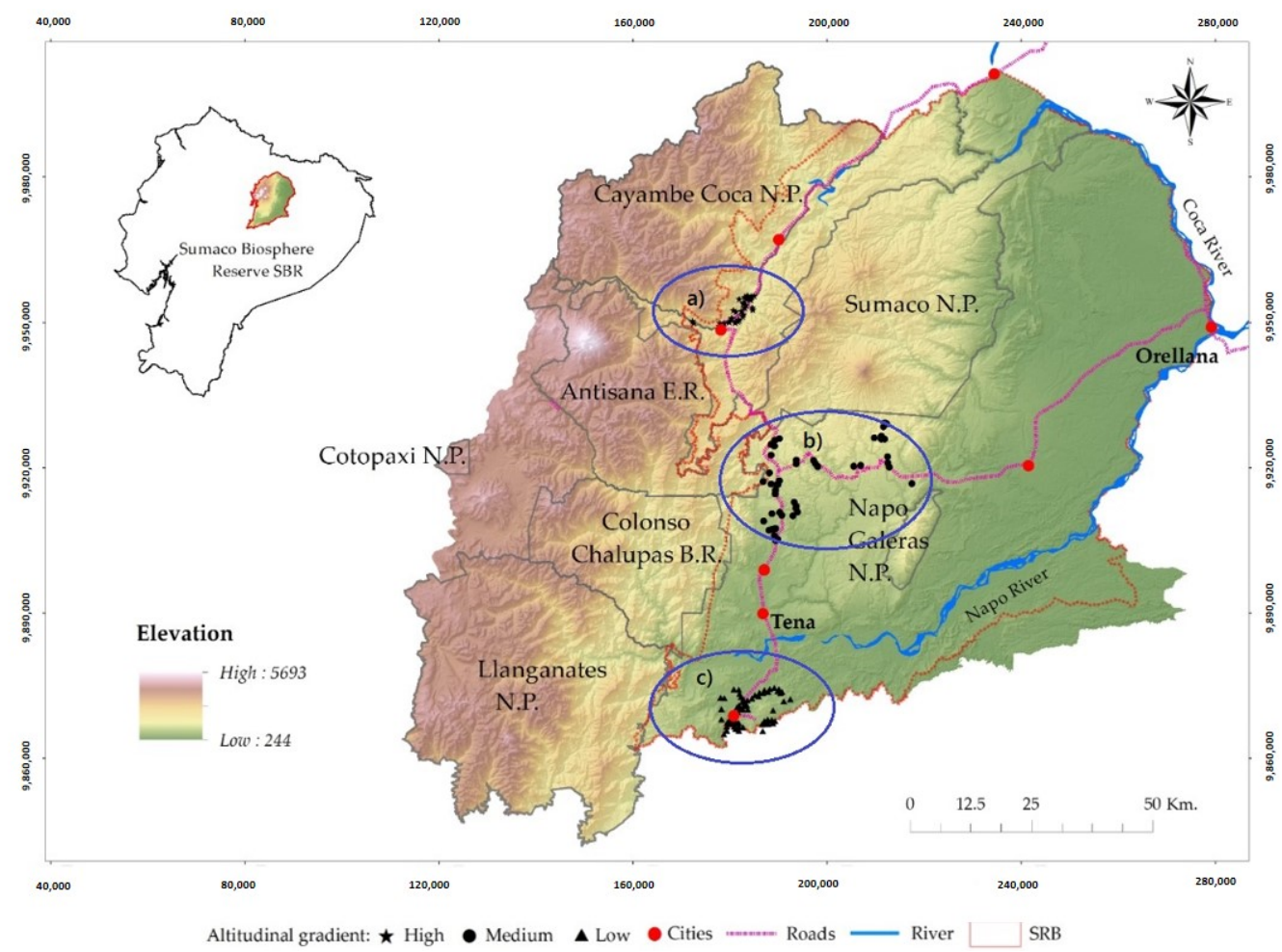

Figure 1. Study area in Napo province (Ecuador). Locations of households along the elevational gradients of the pastoral systems: (a) high zone; (b) medium zone; (c) low zone. Napo, Ecuador.

\subsection{Sampling and Data Collection}

The study was carried out in the buffer and transition zone of the Sumaco Biosphere Reserve (SBR) in the northern and central part of the EAR, mainly in the province of Napo. From a total of 464 households along an elevational gradient mainly in the Napo province of the SBR, we selected a subset of households that had herds containing at least 10 heads of cattle with more than 3 years of consecutive dual-purpose (both milk and meat) production activity [34].

In total, 167 households were interviewed by stratified randomized sampling with proportional assignation in the three elevational gradients: 57 farms in the low zone, 57 in the medium zone, and 53 in the high gradient. All farms were located in the SBR: 
Quijos (San Francisco de Borja), Archidona (Cotundo), and Carlos Julio Arosemena Tola. Information was collected via farm visits and in situ interviews, which were performed by the same person.

Livestock activity along the elevational gradient began with different settlement histories. The high zone, between 1601 and 2000 masl, was settled first, followed by the low zone, between 400 and 700 masl (45 years ago), and, lastly, the middle zone, between 701 and 1600 masl. Our reasons for selecting these three zones were based on ecology, local knowledge, and settlement history. In addition, the elevational gradient (zone) was considered a fixed factor, as we were interested in the potential differences between the zones.

Table 1 shows the 22 items that were evaluated, focusing on the social, structural, and technical characteristics. The items included eight sociodemographic variables; seven on land-use; and seven on structure, income, investments, and net benefits. The selected variables for analysis are shown in Table 1. To determine the total cost per household, all fixed costs (lease of land and maintenance of facilities), financial expenses (interest payments on loans), and variable costs (purchase of livestock, various inputs, and pasture maintenance) were considered. The net profit per household was obtained from the net income minus total costs.

Table 1. Social and structural variables in Napo, SBR, Ecuadorian Amazon, 2015.

\begin{tabular}{|c|c|}
\hline Variables & Description \\
\hline \multicolumn{2}{|l|}{ Sociodemographic characteristics } \\
\hline Settlement, y & Year of settlement of the farm \\
\hline Ethnicity, \% & Household head is Kichwa $(0 / 1)$ \\
\hline Household size, $\mathrm{n}^{\circ}$ & Number of household members \\
\hline Household labor, $\mathrm{n}^{\circ}$ & Number of household members working on the farm \\
\hline Generational replacement, \% & $\begin{array}{l}\text { What percentage of children consider continuing with the activity in the future and } \\
\text { what percentage, on the contrary, consider leaving the occupation? }\end{array}$ \\
\hline Age of household head, y & Age of household head in years \\
\hline Without regulated education, $\%$ & Percent of household heads without formal education \\
\hline Primary education, $\%$ & Percent of household heads with at least formal primary education \\
\hline Secondary education, $\%$ & Percent of household heads with at least formal secondary education \\
\hline \multicolumn{2}{|l|}{ Land-use } \\
\hline Pastureland, ha & Pasture area per farm \\
\hline Cropland, ha & Crop area per farm \\
\hline Remaining forest land, ha & Land for forest \\
\hline Total land, ha & Total surface per farm \\
\hline Forage types & Percentage of grass and legume species in each farm \\
\hline \multicolumn{2}{|l|}{ Structure and economic performance } \\
\hline Total animal units, UA & Total animals by household. Animals of different categories are included \\
\hline Breeds & Type of cattle used. Most frequent breeds in each farm \\
\hline Total investment, \$ & Total household investment amount in livestock and facilities without amortization \\
\hline Total gross income, $\$$ & Total gross income from livestock. Total costs (fixed and variables) were considered \\
\hline Net profit, \$ & Total net profit from livestock \\
\hline
\end{tabular}




\subsection{Statistical Analysis}

A total of 167 cattle farms were analyzed for different parameters. All data were assessed for normal distribution using a Kolmogorov-Smirnoff test, and for homogeneity of variance with a Levene test. The elevational gradient factor was evaluated using the general linear model (GLM). When a significant effect was detected, the least-square means were compared using the Student-Newman-Keuls test (metric variables). Chi-square tests and contingency tables were used to determine associations between non-metric variables [35]. Differences were considered statistically significant when $p$ was lower than 0.05. It is considered appropriate to use low-medium significance levels for both inputs and outputs in dual-purpose systems with high variability [35]. All data were processed using the IBM SPSS (2013) statistical system (Version 22), Inc., Chicago, IL, USA on Windows.

\subsection{Designing and Assessing Best Management Practices (BMPs)}

We developed best practices through an analysis of the literature followed by workshops with a multidisciplinary panel of 15 stakeholders and researchers. It should be highlighted that, for each suggested practice, a series of desirable and adaptable criteria were developed for each of the three zones (elevational gradients), based on several aspects including climatic conditions, culture, proximity to the road, and interest of local governments to contribute to the vision of the REDD+ action plan. Ultimately, 34 potential BMPs were pre-selected (Table S1). The panel of stakeholders was selected intentionally to include livestock community leaders, extensionists, technicians, and scholars. All panel members have specialized interests and experience in sustainable cattle ranching systems, livelihoods, and climate change. Using this multidisciplinary panel of stakeholders and researchers, for each elevational gradient, we collected information to assess the best management practices (BMPs) recommended for livestock systems.

During the workshop with the 15 experts, each pre-selected BMP was analyzed and addressed according to its relevance in the dual-purpose system's context. Selection of the final BMPs started after ensuring the adequacy and appropriateness of the list of preselected BMPs. This way, the experts assessed each BMP on a Likert scale from one to five, where one was the least important, and five was the most important [36]. In the first round of assessment, the BMPs that obtained the maximum score (five) from nine or more experts were selected, and the BMPs that obtained the minimum (one) score from nine experts were discarded. In the second round, descriptive information from the set of responses (concordance index and mean) was sent to each expert to re-examine and reconsider his or her decision. The Ishikawa index was utilized based on the concordance level [37]. We selected BMPs with over $60 \%$ of the concordance level and an average score over 3.5. Ultimately, 16 management practices (BMPs) were selected.

The following section uses the cross-sectional study results to examine sociodemographic characteristics at the household level, land-use at the farm level, livestock management systems, and financial/income-based factors.

\section{Results}

\subsection{Characterization of Farms in Three Elevational Gradients}

In the results, the ethnicity of the household heads presented statistically significant differences. Most of the Kichwa population were found to live in the medium zone (56.1\%). Moreover, the household size in the medium zone (6.7) was greater than that in the other two zones. The year of settlement did not allow us to obtain significant differences in management or economic performance. The medium zone presented a higher percentage (78.9\%) of households with generational replacement. Furthermore, access to credit for the dairy cattle system was higher in the high zone (24.5\%) than in the other zones (Table 2). A high level of illiteracy and a high number of heads of households without formal education $(15.8 \%)$ were observed in the medium elevational gradient, where $56.1 \%$ were Kichwa with livestock-based livelihood strategies. In the low zone, there was a higher percentage $(61.4 \%)$ of cattle ranchers with a primary school education, which could be due to their 
shorter distance to educational centers and the easy access of those centers. In the high zone, $50 \%$ of the heads of households had a secondary education.

Table 2. Characteristics of livestock producers along elevational gradients, Napo, SBR, Ecuadorian Amazon, 2015.

\begin{tabular}{|c|c|c|c|c|c|}
\hline \multirow{2}{*}{ Variables } & \multicolumn{3}{|c|}{ Elevational Gradients (Zones) } & \multicolumn{2}{|c|}{ Statistical Test } \\
\hline & Low & Medium & High & F-Snedecor & $p$-Value ${ }^{1}$ \\
\hline \multicolumn{6}{|l|}{ Sociodemographic characteristics } \\
\hline Average elevation, masl & $543.1^{\mathrm{a}}$ & $1114.1^{\mathrm{b}}$ & $1778.0^{\mathrm{c}}$ & 816.58 & 0.001 \\
\hline Settlement, y & 1975 & 1984 & 1952 & 0.58 & n.s. \\
\hline Ethnicity, \% & 0.0 & 56.1 & 0.0 & 0.43 & 0.001 \\
\hline Household size, $\mathrm{n}^{\circ}$ & $5.56^{\mathrm{a}, \mathrm{b}}$ & $6.70^{a}$ & $5.04^{b}$ & 1.04 & 0.01 \\
\hline Household labor, $n^{\circ}$ & 2.63 & 3.00 & 2.32 & 0.75 & n.s \\
\hline $\begin{array}{l}\text { Generational replacement } \\
(\text { Yes, \%) }\end{array}$ & $56.1^{\mathrm{a}}$ & $78.9^{b}$ & $56.6^{\mathrm{a}}$ & 8.73 & 0.01 \\
\hline Age of household head, $y$ & 54.79 & 56.77 & 57.60 & 0.71 & n.s. \\
\hline $\begin{array}{l}\text { Without regulated } \\
\text { education, \% }\end{array}$ & 8.8 & 15.8 & 3.8 & 4.83 & n.s. \\
\hline Primary education, $\%$ & 61.4 & 47.4 & 28.3 & 12.46 & 0.002 \\
\hline Secondary education, $\%$ & 22.8 & 24.6 & 49.1 & 11.57 & 0.003 \\
\hline \multicolumn{6}{|l|}{ Land-use } \\
\hline Pastureland, ha & $26.8 \pm 19.2$ & $27.2 \pm 28.6$ & $22.5 \pm 17.2$ & 18.49 & 0.001 \\
\hline Crops land, ha & $1.6^{\mathrm{a}} \pm 1.9$ & $2.2^{\mathrm{a}} \pm 3.3$ & $0.4^{\mathrm{b}} \pm 1.1$ & 17.32 & 0.001 \\
\hline Remaining forest land, ha & $20.1^{\mathrm{a}, \mathrm{b}} \pm 29.8$ & $32.9^{a} \pm 56.2$ & $12.2^{b} \pm 28.1$ & 22.35 & 0.05 \\
\hline Total land, ha & $47.3^{\mathrm{a}, \mathrm{b}} \pm 42.1$ & $62.4^{\mathrm{a}} \pm 70.6$ & $35.2^{b} \pm 40.2$ & 0.73 & 0.05 \\
\hline \multicolumn{6}{|l|}{ Forage } \\
\hline Grasses, \% & 60 & 86.7 & 91.7 & 77.82 & 0.05 \\
\hline Legumes, \% & 40 & 13.3 & 8.3 & 12.10 & 0.05 \\
\hline \multicolumn{6}{|l|}{ Economic performance } \\
\hline Total animal unit, UA & $24.2^{\mathrm{a}} \pm 13.8$ & $18.8^{\mathrm{a}, \mathrm{b}} \pm 17.1$ & $30.4^{\mathrm{b}} \pm 21.8$ & 5.82 & 0.01 \\
\hline Breeds & $\begin{array}{l}\text { Creole, Charoles, } \\
\text { Santa Gertrudis } \\
\text { and Jersey }\end{array}$ & $\begin{array}{l}\text { Creole, Brown } \\
\text { Swiss and } \\
\text { Brahman }\end{array}$ & $\begin{array}{l}\text { Holstein and } \\
\text { Normando }\end{array}$ & & \\
\hline Total investment, \$ & $1709.9^{b} \pm 1547.1$ & $1555.8^{\mathrm{b}} \pm 1403.7$ & $4307.3^{a} \pm 2814.7$ & 32.42 & 0.001 \\
\hline Total gross income, $\$$ & $2762.7^{b} \pm 3038.1$ & $3415.1^{b} \pm 4939.6$ & $19,042.6^{a} \pm 26,204.6$ & 20.11 & 0.001 \\
\hline Net profit, \$ & $1052.7^{b} \pm 3259.3$ & $1859.3^{b} \pm 4682.1$ & $14,735.3^{a} \pm 25,120.3$ & 15.15 & 0.001 \\
\hline
\end{tabular}

${ }^{1}$ ANOVA for continuous variables and $X^{2}$ for discrete variables; n.s. $p>0.05-$ no significance. Letters in superscript denote significant differences among elevational gradients.

The comparative results of land-use and farm size among the three groups shown in Figure 2 indicate that, from the 62.4 hectares in the medium zone, on average, $55 \%$ of the land is used for growing pastures, $40 \%$ is covered by forest, and the rest is dedicated to crops. Subsequently, $62 \%$ of the average hectare in the low zone is pastureland, $34 \%$ is forest land, and $5 \%$ is crop land. Land in the highland area is mostly used to produce pastures $(81 \%)$, while $17 \%$ is covered by forest, and only $2 \%$ is used for crops. Farms in the three zones were focused on raising cattle, particularly in the high (dairy and meat) and low (meat and dairy) zones, while the medium zone was found to feature a greater area of forest. However, the availability of agricultural land in the three zones was very low. 

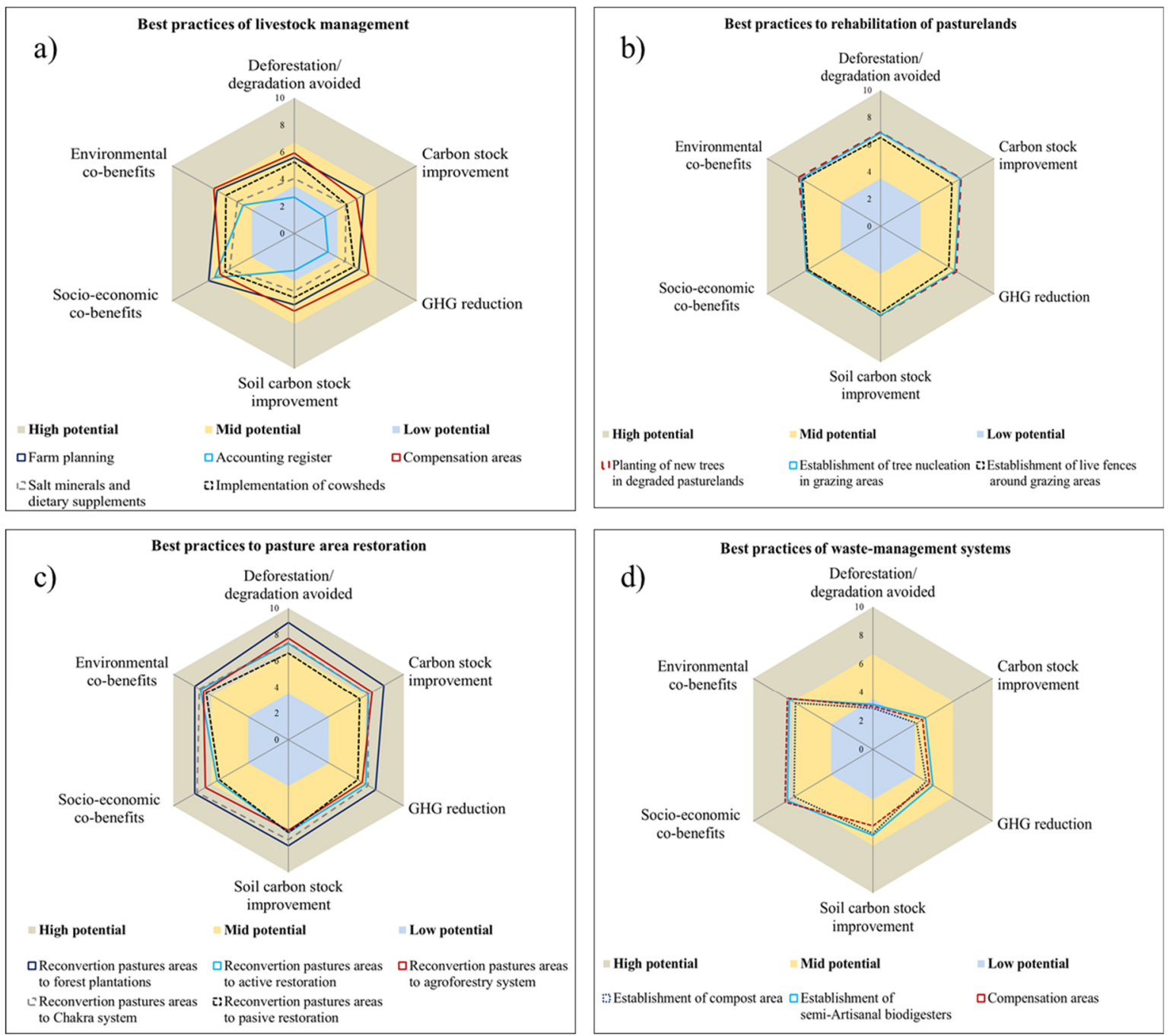

Figure 2. Assessment of BMPs identified as having potential for: (a) livestock management, (b) the rehabilitation of pasturelands, (c) pasture area restoration, and (d) waste-management systems. Napo, Ecuador.

The total stock of cattle was significantly greater in the low zone (30.4 animal units) than in the other research sites. Nevertheless, the annual net benefit was the lowest (\$1053). The existing climatic variables in the 400-700 masl zone play an important role in the adequate management of cattle production, which is reflected in the annual income (\$1053). If this value is transformed into a monthly income, farmers in this zone earned an average of USD 87.75, while households in the high zone, with an average of 24.3 animal units, annually earned USD 14735, which represents a monthly income of \$ 1228 (Figure 2).

\subsection{Identification of Best-Recommended Livestock BMPs}

Table 3 shows the 16 BMPs evaluated under the six REDD+ actions and grouped by their contribution to improving livestock management (1), rehabilitating pastureland (2), promoting the reconversion of pasture areas (3), and implementing waste-management systems (4) in the three zones (Table 3). Likewise, the measures were classified as having high, medium, or low potential impacts. Thus, a practical and direct guide was proposed, where the higher-impact BMPs could be visualized (Figure 2). 
Table 3. Livestock BMPs recommended and assessed along the elevational gradient.

\begin{tabular}{|c|c|c|c|c|}
\hline Components & Best Management Practices (BMPs) & Low Zone & $\begin{array}{l}\text { Medium } \\
\text { Zone }\end{array}$ & High Zone \\
\hline \multirow{5}{*}{$\begin{array}{l}\text { 1. Improvement of } \\
\text { livestock management }\end{array}$} & \multirow{5}{*}{$\begin{array}{l}\text { Farm planning } \\
\text { Implementation of accounting registers } \\
\text { Implement compensation area } \\
\text { Implementation of fences with sheds } \\
\text { Improvement of animal diet with salt minerals and } \\
\text { dietary supplements }\end{array}$} & $\sqrt{ } \checkmark \sqrt{ }$ & $\sqrt{ } \checkmark \sqrt{ }$ & $\sqrt{ } \checkmark \sqrt{ }$ \\
\hline & & $\checkmark \sqrt{ }$ & $\checkmark \checkmark$ & $\checkmark \checkmark$ \\
\hline & & $\checkmark$ & $\checkmark$ & $\checkmark$ \\
\hline & & $\checkmark \sqrt{ }$ & $\sqrt{ }$ & $\sqrt{ }$ \\
\hline & & $\checkmark \checkmark \checkmark$ & $\checkmark \checkmark \checkmark$ & $\checkmark \checkmark \checkmark$ \\
\hline \multirow{3}{*}{$\begin{array}{l}\text { 2. Rehabilitation of } \\
\text { pasturelands }\end{array}$} & $\begin{array}{l}\text { Planting of new trees in degraded and non-degraded } \\
\text { pasturelands }\end{array}$ & $\sqrt{ } \sqrt{ }$ & $\checkmark \checkmark \checkmark$ & \\
\hline & Establishment of tree nucleation around grazing areas ${ }^{1}$ & $\checkmark \checkmark$ & $\checkmark \checkmark$ & $\checkmark \checkmark$ \\
\hline & Establishment of live fences around grazing areas & $\checkmark$ & $\checkmark$ & $\checkmark$ \\
\hline \multirow{5}{*}{$\begin{array}{l}\text { 3. Pasture area } \\
\text { restoration }\end{array}$} & Forest plantations & $\sqrt{ } \checkmark \sqrt{ }$ & $\sqrt{ } \sqrt{ }$ & - \\
\hline & Active restoration & $\checkmark \sqrt{ }$ & $\checkmark \sqrt{ }$ & - \\
\hline & Passive restoration & $\checkmark \checkmark$ & $\checkmark \sqrt{ }$ & - \\
\hline & Agroforestry system & $\checkmark$ & & - \\
\hline & Chakra system & $\checkmark \sqrt{ }$ & $\checkmark \checkmark \checkmark$ & - \\
\hline \multirow{3}{*}{$\begin{array}{l}\text { 4. Implementation of } \\
\text { waste-management } \\
\text { systems }\end{array}$} & Artisanal lombriculture & $\checkmark$ & $\checkmark$ & $\checkmark$ \\
\hline & Compost area & $\checkmark \checkmark \checkmark$ & $\checkmark \checkmark \checkmark$ & $\checkmark \sqrt{ }$ \\
\hline & Semi-artisanal biodigesters & $\checkmark \checkmark$ & $\checkmark \checkmark$ & $\checkmark \sqrt{ }$ \\
\hline
\end{tabular}

$\checkmark \checkmark \checkmark$ High potential; $\checkmark \checkmark$ Medium potential; $\checkmark$ Low potential. ${ }^{1}$ Vegetative propagation technique to speed up the process of succession through the use of tree and shrub stakes, creating vegetation clusters inside pasture areas.

Figure 2a shows that farm planning and accounting registers have high potential to achieve socioeconomic benefits. The BMPs of the compensation areas present medium potential to achieve environmental co-benefits, avoid deforestation or degradation, reduce GHG emissions, and improve the soil carbon stock. The building of fences with sheds has medium potential to achieve all six benefits, particularly those related to deforestation and avoiding degradation.

Figure $2 \mathrm{~b}$ shows that the rehabilitation of the pastureland component by planting new trees in degraded pasturelands has medium potential for all six benefits. The establishment of live fences around grazing zone areas has high to medium potential to achieve environmental, soil carbon stock, and socioeconomic benefits, to improve the carbon stock, and to reduce GHGs.

The component of pasture area restoration that includes the BMPs for promoting the reconversion of pasture areas to forest plantations has high potential to avoid degradation and deforestation. Likewise, the reconversion of pasture areas to chakra systems has high potential to contribute to all six benefits but primarily provides socioeconomic cobenefits. Finally, the reconversion of pasture areas to passive restoration has high potential to provide environmental co-benefits and improve the soil carbon stock (Figure 2c).

Among the BMPs related to the implementation of the waste-management system component shown in Figure 2d, the compensation areas and the establishment of semi-artisanal biodigesters have high potential to achieve environmental and socioeconomic co-benefits, and low potential to avoid deforestation and degradation. Furthermore, the establishment of the compost area has medium potential for environmental and socioeconomic co-benefits, and, like other BMPs, low potential to avoid deforestation and degradation.

\section{Discussion}

Indigenous populations, who have experienced almost 60 years of colonization, ancestrally inhabited the area, which is considered to be a biodiversity "hotspot" under severe threat [31]. The current protection of the SBR promotes biodiversity conservation, sustainable development, education, and research as a means of reconciling humans and nature. The first settlements appeared 70 years ago in the high zone, 45 years ago in the low 
zone, and 35 years ago in the middle zone. The average age of the head of the household in the study area was over 50, a similar value to that of land-owning producers of small livestock species at low altitudes in Napo Province [18]. The adoption of unsustainable productive dynamics similar to those of migrant settlers was observed [38,39], which could be due to the proximity to roads and the market economy [40,41]. However, it is important to consider the results of Torres et al. [18], who reported that Kichwa households involved in livestock-based livelihood strategies obtain significantly lower incomes from this activity than migrant settlers. For household size, the values (5.3) were similar to those reported by Kichwa smallholders in the southern EAR [40] and those reported in the Yasuni Biosphere Reserve [42]. These values were higher than those reported for Kichwa smallholder cattle ranching households in the central Andes of Ecuador (3.8) [43].

Sustainable production improvements have been widely studied $[4,5,44]$. In this context, understanding the Best Management Practices (BMPs) for controlling and reducing natural resource degradation (forest, land, and water) is essential to design more sustainable systems. In Latin America, land-use change to grasslands has become one of the main causes of tropical forest destruction [45]. Through our analysis, we compared the livestock farming systems among different ecological zones in the Ecuadorian Amazon Region, linking these systems to economic performance. Then, we identified the best practices selected for each region. Lastly, we will discuss the assessment of best practices related to land-use changes, REDD+ actions, restoration of pasturelands, and co-benefits.

\subsection{How and to What Extent BMPS Contribute to the REDD+Approach and the Conversion of Pasturelands to Other Sustainable Uses}

The BMPs were selected based on the following factors: (a) current deforestation trends considering increased demand for agricultural products [29]; (b) the priorities of the Ministry of Environment and Water (MAAE) within the framework of the REDD+ action plan [6]; and (c) the different incentive programs in Ecuador, such as ATPA, the MAAE's Socio Bosque Program, the MAAE, and MAG's program (ProAmazonia). All the identified BMPs were proposed based on their applicability and technical feasibility in the area, the availability of the facilities on their farms, the observation of major impacts from greenhouse gas reductions and carbon sequestration, and the presence of a direct contribution to economic and environmental co-benefits. These BMPs were divided into the four components assessed (Table 3) for improving livestock management.

For BMP studies of cattle ranching, combining BMPs yielded the greatest change, since a combination of BMPs is always better than using a single type [46]. In this context, farm planning and the implementation of accounting registers, compensation areas, cowsheds, and improvements in animal diet with salt minerals and dietary supplements should be most effective if a whole-farm management plan cannot be implemented with all the necessary BMPs. In the cattle ranching sector, the main contributions to sustainability come from the adequate use of economic and natural resources and the implementation of effective feeding strategies [47]. Sustainable development is important to understand the trade-off between farming profitability and environmental protection [48]. Considering the best management practices to improve cattle-raising will contribute to the long-term sustainable development of farming [49].

\subsubsection{BMPs for the Rehabilitation of Pasturelands}

We recommend improving grasslands using the BMPs, including planting trees, as well as using tree nucleation models and live fences to increase production and profits and reduce damage to the environment among households engaging in livestock-based livelihood strategies [18]. On this issue, the livelihood approach could be used to identify the acceptance of producers to convert less efficient or abandoned pasture areas into more sustainable production systems, as proposed by Torres and others [50] in the same study area. The benefits of BMPs were related to increased pasture resistance, a greater number of animal units per hectare, higher cattle weight, the presence of continuous pasture, decreased feeding costs, and soil erosion [33]. Using the recommended BMPs to 
recover pasturelands in the Amazon could help deflect the current pressure of establishing farmland, reduce deforestation and the emissions of GHGs, and increase the carbon stock. These results are consistent with those of Fernandes and others [51], who highlighted the importance of rehabilitating pastureland based on its value for human use and ability to provide ecosystem services and carbon sinks.

Applying nucleation as a reforestation strategy can significantly improve forest diversity and structure, thereby increasing many ecological services [52]. For instance, by 2040, the adoption of sustainable pasture management in Brazil is projected to increase the productivity of pasture-based products by up to 50\% [53]. Furthermore, the implementation of live fences to protect grazing areas as a BMP have productive and ecological benefits. Live fences can be a source of fodder, wild fruits, firewood, and carbon sequestration, while providing resources and acting as habitat for other animals. As shown in similar studies in Central America [54], the joint utility of live fences for production and biodiversity conservation should be the subject of greater research attention as a sustainable management strategy. An understanding of these factors could help policy makers to design new policies regarding the rehabilitation of pasturelands to improve socioeconomic constraints and handle degradation phenomena.

\subsubsection{BMPs for Forest Restoration}

Local people plant trees in association with food crops, thus creating resource agroforestry islands in open degraded pastures with more than 100 species [51] and reducing the amount of land in the livestock system - not only via intensification, as suggested by Green et al. [55] and Phalan et al. [56], but also due to soil impoverishment and degradation. Reforestation can, moreover, introduce economic development to deprived rural areas and create lasting livelihood benefits [57].

The BMPs suggested to promote the reconversion of pasture areas are recommended in the low and medium zones due to the socioeconomics and cultural characteristics of the areas. In these zones, the traditional agroforestry system known as Chakra uses locally adapted patterns of sustainable development and a strong interaction of cultural, biosocial, and environmental aspects embedded in the traditional Kichwa worldview [26,27]. However, rapid deforestation and a significant loss of biodiversity threaten the indigenous agroforestry systems and modify their socioeconomic and environmental conditions [58]. Therefore, the restoration of pasture areas by afforestation as a BMP strategy in the framework of REDD+, and payment for ecosystem services (PES) provide an opportunity to improve the capacity of landscape carbon storage and create the conditions for re-establishing ecosystem services. In this regard, Knoke et al. [59] suggested afforestation as the best option for local farmers to effectively integrate abandoned pasturelands into the production cycle with high socioeconomic and ecological value in southern Ecuador. Therefore, the prioritization of pasture areas for restoration is urgently needed; otherwise, due the lack of sustainable management, the degradation process will continue [60].

Finally, in light of the results (Table 3 and Figure 2), we suggest the following: In the high zone, it is recommended to start with BMPs that contribute to improving livestock management and the rehabilitation of pasturelands. Additionally, in the medium and low zones, it would be easier to start with BMPs, with a focus on promoting the restoration of pasture areas and improving livestock management.

\subsubsection{BMPs for Implementing Waste-Management Systems}

The findings in this study show that the establishment of artisanal lombriculture, compost areas, and semi-artisanal biodigesters are BMPs that allow for adaptions able to improve the socioeconomic and environmental co-benefits for farm households. Furthermore, adaptive management allows the conservation of forests [61] and contributes to resilience towards adverse economic conditions [62]. The best practices of waste-management systems are built from knowledge from social networks within and among communities [63]. However, livestock BMP research does not often integrate social or human factors. This study 
contributes to the understanding that socioeconomic and environmental benefits emerge from knowledge that allows adaptive learning, which influences farmers' decisions to implement different BMP strategies that can facilitate sustainable livestock intensification.

\subsection{Policy Implications for Implementation}

The evaluated BMPs could facilitate the development of mechanisms to improve existing national financial incentive programs related to livestock, as well as encourage public-private partnership structures and the roles they play as key local actors in potential REDD+ projects. Our findings could also facilitate discussions between impact investment funds and multilateral funders that have committed to support REDD+ projects. To this end, it will be necessary to develop partnerships for specific interventions among several stakeholders $[64,65]$. However, it is also necessary to consider other factors such as technical assistance, livestock technologies, local capacity building, and off-farm employment to achieve the dual objectives of improving productivity through increased yields and releasing land for restoration purposes. The effectiveness of BMPs is often dependent on other factors, including proper installation and maintenance and the selection of appropriate practices for a given combination of households and farm characteristics. The development of a technical assistance package is proposed to ensure the full implementation of the 16 recommended BMPs.

Additional long-term analyses will be required to validate these assumptions and assess the technical and financial feasibility of implementing and monitoring these practices. In addition to their impacts on land-use change, a thorough analysis of the impact of changes in animal diet, as the most significant source of greenhouse gases (GHGs) from livestock activity, should be conducted.

\section{Conclusions}

This research contributes to a characterization of the farms along the elevational gradient in the upper Ecuadorian Amazon. Cattle specialized in milk production predominate in the upper area, and dual-purpose cattle (meat and dairy) are most common in the lower area. The Kichwa population was found to be concentrated in the middle zone and presented a livelihood system with agricultural, forestry, and livestock activity. This study provides an evaluation of $16 \mathrm{BMPs}$ oriented to improve the sustainability of farms in the upper Ecuadorian Amazon along an elevation. The application of BMPs by stakeholders contributes to various REDD+ objectives for restoring and enhancing pasturelands, and many of these practices will influence climate change mitigation.

Supplementary Materials: The following are available online at https:/ / www.mdpi.com/article/10 .3390/agronomy11071336/s1, Table S1: Livestock Best Management Practices (BMPs) pre-selected.

Author Contributions: B.T., C.B. and C.V. carried out the fieldwork research in this study. B.T., C.B., Y.T. and C.V. analyzed the data and compiled the literature. B.T., D.E., C.B., Y.T., C.V. and A.G. prepared the text, provided revisions, and approved the final manuscript. All authors have read and agreed to the published version of the manuscript.

Funding: This research received no external funding.

Data Availability Statement: The data are available on request from the corresponding author.

Acknowledgments: The authors would like to thank Deutsche Gesellschaft für Internationale Zusammenarbeit (GIZ), through the REDD+ Early Movers Program (REM), and Rainforest Alliance Inc., who provided financial and technical support during the fieldwork, as well as the Ministry of agriculture and livestock (MAG), the Ministry of environment and water (MAAE), and Universidad Estatal Amazónica (UEA) for their support during the field and desk research. We also thank the families of the three zones who shared valuable information about their livestock activities.

Conflicts of Interest: The authors declare no conflict of interest. 


\section{References}

1. Ritchie, H.; Roser, M. Land Use-Our World in Data. Available online: https:// ourworldindata.org/land-use (accessed on 18 March 2021).

2. Gerber, P.; Steinfeld, H.; Henderson, B.; Mottet, A.; Opio, C.; Dijkman, J.; Falcucci, A.; Tempio, G. Tackling Climate Change through Livestock: A Global Assessment of Emissions and Mitigation Opportunities; FAO: Rome, Italy, 2013; ISBN 9789251079201.

3. Lerner, A.M.; Zuluaga, A.F.; Chará, J.; Etter, A.; Searchinger, T. Sustainable Cattle Ranching in Practice: Moving from Theory to Planning in Colombia's Livestock Sector. Environ. Manag. 2017, 60, 176-184. [CrossRef]

4. Foley, J.A.; Ramankutty, N.; Brauman, K.A.; Cassidy, E.S.; Gerber, J.S.; Johnston, M.; Mueller, N.D.; O'Connell, C.; Ray, D.K.; West, P.C.; et al. Solutions for a cultivated planet. Nature 2011, 478, 337-342. [CrossRef] [PubMed]

5. Boval, M.; Angeon, V.; Rudel, T. Tropical grasslands: A pivotal place for a more multi-functional agriculture. Ambio 2017, 46, 48-56. [CrossRef]

6. Ministerio del Ambiente del Ecuador (MAE). Bosques Para el Buen Vivir-Plan de Acción REDD+ Ecuador (2016-2025); Quito, Ecuador, 2016; ISBN 9789942220790.

7. Sierra, R. Patrones y Factores de Deforestación en el Ecuador Continental, 1990-2010. Y un Acercamiento a los Próximos 10 Años; Conservación Internacional Ecuador, Forest Trends: Quito, Ecuador, 2013.

8. Wasserstrom, R.; Bustamante, T. Ethnicity, Labor and Indigenous Populations in the Ecuadorian Amazon, 1822-2010. Adv. Anthropol. 2015, 5, 1-18. [CrossRef]

9. Baynard, C.W.; Ellis, J.M.; Davis, H. Roads, petroleum and accessibility: The case of eastern Ecuador. GeoJournal 2013, 78, 675-695. [CrossRef]

10. Finer, M.; Jenkins, C.N.; Pimm, S.L.; Keane, B.; Ross, C. Oil and gas projects in the Western Amazon: Threats to wilderness, biodiversity, and indigenous peoples. PLoS ONE 2008, 3, e2932. [CrossRef]

11. Suárez, E.; Morales, M.; Cueva, R.; Utreras Bucheli, V.; Zapata-Ríos, G.; Toral, E.; Torres, J.; Prado, W.; Vargas Olalla, J. Oil industry, wild meat trade and roads: Indirect effects of oil extraction activities in a protected area in north-eastern Ecuador. Anim. Conserv. 2009, 12, 364-373. [CrossRef]

12. Leifsen, E. The socionature that neo-extractivism can see: Practicing redistribution and compensation around large-scale mining in the Southern Ecuadorian Amazon. Polit. Geogr. 2020, 82, 102249. [CrossRef]

13. Gray, C.L.; Bilsborrow, R.E.; Bremner, J.L.; Lu, F. Indigenous land use in the Ecuadorian Amazon: A cross-cultural and multilevel analysis. Hum. Ecol. 2008, 36, 97-109. [CrossRef]

14. Mejia, E.; Pacheco, P.; Muzo, A.; Torres, B. Smallholders and timber extraction in the Ecuadorian Amazon: Amidst market opportunities and regulatory constraints. Int. For. Rev. 2015, 16, 1-13. [CrossRef]

15. Mena, C.F.; Bilsborrow, R.E.; McClain, M.E. Socioeconomic drivers of deforestation in the Northern Ecuadorian Amazon. Environ Manag. 2006, 37, 802-815. [CrossRef]

16. MAGAP ATPA. Reconversión Agro productiva Sostenible en la Amazonía Ecuatoriana; Ministerio de Agricultura y Ganadería: Quito, Ecuador, 2014.

17. Lerner, A.M.; Rudel, T.K.; Schneider, L.C.; McGroddy, M.; Burbano, D.V.; Mena, C.F. The spontaneous emergence of silvo-pastoral landscapes in the Ecuadorian Amazon: Patterns and processes. Reg. Environ. Chang. 2014, 15, 1421-1431. [CrossRef]

18. Torres, B.; Günter, S.; Acevedo-Cabra, R.; Knoke, T. Livelihood strategies, ethnicity and rural income: The case of migrant settlers and indigenous populations in the Ecuadorian Amazon. For. Policy Econ. 2018, 86, 22-34. [CrossRef]

19. Bravo, C.; Torres, B.; Alemán, R.; Marín, H.; Durazno, G.; Navarrete, H.; Gutiérrez, E.T.; Tapia, A. Indicadores morfológicos y estructurales de calidad y potencial de erosión del suelo bajo diferentes usos de la tierra en la Amazonía ecuatoriana. An. Geogr. Univ. Complut. 2017, 37, 247-264. [CrossRef]

20. Alemán, R.; Bravo, C.; Vargas, J.C.; Chimborazo, C. Agroecological typification of livestock production systems in the Ecuadorian Amazon region. Livest. Res. Rural Dev. 2020, 32, 95. Available online: http://www.lrrd.org/lrrd32/6/cbravo32095.html (accessed on 18 March 2021).

21. Asamblea Nacional, R. del E. Código Orgánico del Ambiente. Available online: http:/ / extwprlegs1.fao.org/docs/pdf/ecu16711 6.pdf (accessed on 18 March 2021).

22. Jadán, O.; Günter, S.; Torres, B.; Selesi, D. Riqueza y potencial maderable en sistemas agroforestales tradicionales como alternativa al uso del bosque nativo, Amazonía del Ecuador. Rev. For. Mesoam. Kurú 2015, 12, 13-22. [CrossRef]

23. Vera, V.R.R.; Cota-Sánchez, J.H.; Grijalva Olmedo, J.E. Biodiversity, dynamics, and impact of chakras on the Ecuadorian Amazon. J. Plant Ecol. 2019, 12, 34-44. [CrossRef]

24. Torres, B.; Jadan, O.; Aguirre, P.; Hinojosa, L.; Guenter, S. The contribution of traditional agroforestry to climate change adaptation in the Ecuadorian Amazon: The chakra system. In Handbook of Climate Change Adaptation; Leal Filho, W., Ed.; Springer: Berlin/Heidelberg, Germany, 2015; pp. 1973-1994. ISBN 9783642386695.

25. Jadán, O.; Torres, B.; Selesi, D.; Peña, D.; Rosales, C.; Gunter, S. Diversidad Florística Y Estructura En Cacaotales Tradicionales Y Bosque Natural (Sumaco, Ecuador). Colomb. For. 2016, 19, 5-18. [CrossRef]

26. Coq-Huelva, D.; Torres-Navarrete, B.; Bueno-Suárez, C. Indigenous worldviews and Western conventions: Sumak Kawsay and cocoa production in Ecuadorian Amazonia. Agric. Hum. Values 2018, 35, 163-179. [CrossRef]

27. Coq-Huelva, D.; Higuchi, A.; Alfalla-Luque, R.; Burgos-Morán, R.; Arias-Gutiérrez, R. Co-Evolution and Bio-Social construction: The Kichwa agroforestry systems (chakras) in the Ecuadorian Amazonia. Sustainability 2017, 9, 1920. [CrossRef] 
28. Rudel, T.K.; Paul, B.; White, D.; Rao, I.M.; Van Der Hoek, R.; Castro, A.; Boval, M.; Lerner, A.; Schneider, L.; Peters, M. LivestockPlus: Forages, sustainable intensification, and food security in the tropics. Ambio 2015, 44, 685-693. [CrossRef]

29. De-Pablos-Heredero, C.; Montes-Botella, J.L.; García, A. Impact of Technological Innovation on Performance in Dairy Sheep Farms in Spain. J. Agric. Sci. Tech. 2020, 22, 597-610.

30. Myers, N.; Mittermeier, R.A.; Fonseca, G.A.B.; Fonseca, G.A.B.; Kent, J. Biodiversity hotspots for conservation priorities. Nature 2000, 403, 853-858. [CrossRef] [PubMed]

31. Mittermeier, R.A.; Myers, N.; Thomsen, J.B.; da Fonseca, G.A.B.; Olivieri, S. Biodiversity Hotspots and Major Tropical Wilderness Areas: Approaches to Setting Conservation Priorities. Conserv. Biol. 1998, 12, 516-520. [CrossRef]

32. Myers, N. Threatened biotas: "hot spots" in tropical forests. Environmentalist 1988, 8, 187-208. [CrossRef]

33. Borges, J.A.R.; Tauer, L.W.; Lansink, A.G.J.M.O. Using the theory of planned behavior to identify key beliefs underlying Brazilian cattle farmers' intention to use improved natural grassland: A MIMIC modelling approach. Land Use Policy 2016, 55, 193-203. [CrossRef]

34. Rangel, J.; Perea, J.; De-Pablos-heredero, C.; Espinosa-García, J.A.; Mujica, P.T.; Feijoo, M.; Barba, C.; García, A. Structural and technological characterization of tropical smallholder farms of dual-purpose cattle in mexico. Animals 2020, 10, 86. [CrossRef] [PubMed]

35. Rangel, J.; Espinosa, J.A.; de Pablos-Heredero, C.; Rivas, J.; Perea, J.; Angón, E.; García-Martínez, A. Is the increase of scale in the tropics a pathway to smallholders? Dimension and ecological zone effect on the mixed crop-livestock farms. Span. J. Agric. Res. 2017, 15, 109. [CrossRef]

36. Rivas, J.; Perea, J.M.; De-Pablos-Heredero, C.; Angon, E.; Barba, C.; García, A. Canonical correlation of technological innovation and performance in sheep's dairy farms: Selection of a set of indicators. Agric. Syst. 2019, 176, 102665. [CrossRef]

37. García-Martínez, A.; Rivas-Rangel, J.; Rangel-Quintos, J.; Espinosa, J.A.; Barba, C.; de-Pablos-Heredero, C. A methodological approach to evaluate livestock innovations on small-scale farms in developing countries. Future Internet 2016, 8, 25. [CrossRef]

38. Vasco, C.; Torres, B.; Jácome, E.; Torres, A.; Eche, D.; Velasco, C. Use of chemical fertilizers and pesticides in frontier areas: A case study in the Northern Ecuadorian Amazon. Land Use Policy 2021, 107, 105490. [CrossRef]

39. Sellers, S.; Bilsborrow, R. Agricultural technology adoption among migrant settlers and indigenous populations of the Northern Ecuadorian Amazon: Are differences narrowing? J. Land Use Sci. 2019, 14, 347-361. [CrossRef]

40. Vasco, C.; Bilsborrow, R.; Torres, B.; Griess, V. Agricultural land use among mestizo colonist and indigenous populations: Contrasting patterns in the Amazon. PLoS ONE 2018, 13. [CrossRef]

41. Godoy, R.; Jacobson, M.; De Castro, J.; Aliaga, V.; Romero, J.; Davis, A. The role of tenure security and private time preference in neotropical deforestation. Land Econ. 1998, 74, 162-171. [CrossRef]

42. Heredia-R, M.; Torres, B.; Cayambe, J.; Ramos, N.; Luna, M.; Diaz-Ambrona, C.G.H. Sustainability Assessment of Smallholder Agroforestry Indigenous Farming in the Amazon: A Case Study of Ecuadorian Kichwas. Agronomy 2020, 10, 1973. [CrossRef]

43. León, V.; Torres, B.; Luna, M.; Torres, A.; Ramírez, P.; Andrade-Yucailla, V.; Muñoz-Rengifo, J.C.; Heredia-R, M. Perception of climate change in four communities oriented to cattle ranching in the central zone of the Ecuadorian Andes. Livest. Res. Rural Dev. 2020, 32.

44. McGroddy, M.E.; Lerner, A.M.; Burbano, D.V.; Schneider, L.C.; Rudel, T.K. Carbon Stocks in Silvopastoral Systems: A Study from Four Communities in Southeastern Ecuador. Biotropica 2015, 47, 407-415. [CrossRef]

45. Rodríguez, D.I.; Anríquez, G.; Riveros, J.L. Seguridad alimentaria y ganadería: El caso de América Latina y el Caribe. Cienc. Investig. Agrar. 2016, 43, 5-15.

46. Kroll, S.A.; Oakland, H.C. A Review of Studies Documenting the Effects of Agricultural Best Management Practices on Physiochemical and Biological Measures of Stream Ecosystem Integrity. Nat. Areas J. 2019, 39, 58. [CrossRef]

47. Makkar, H.P.S. Smart livestock feeding strategies for harvesting triple gain-The desired outcomes in planet, people and profit dimensions: A developing country perspective. Anim. Prod. Sci. 2016, 56, 519. [CrossRef]

48. Bardos, R.P.; Bone, B.D.; Boyle, R.; Evans, F.; Harries, N.D.; Howard, T.; Smith, J.W.N. The rationale for simple approaches for sustainability assessment and management in contaminated land practice. Sci. Total Environ. 2016, 563-564, 755-768. [CrossRef] [PubMed]

49. Pereira Domingues, V. Best management practices from agricultural economics: Mitigating air, soil and water pollution. Sci. Total Environ. 2019, 688, 346-360. [CrossRef]

50. Torres, B.; Vasco, C.; Günter, S.; Knoke, T. Determinants of agricultural diversification in a hotspot area: Evidence from colonist and indigenous communities in the Sumaco Biosphere Reserve, Ecuadorian Amazon. Sustainability 2018, 10, 1432. [CrossRef]

51. Fernandes, E.; Wandelli, E.; Perin, R.; Garcia, S. Restoring Productivity to Degraded Pasture Lands in the Amazon through Agroforestry Practices. In Biological Approaches to Sustainable Soil Systems; Uphoff, N., Ed.; CRC Press: Boca Raton, FL, USA, 2006; pp. 305-321. ISBN 9781420017113.

52. Corbin, J.D.; Robinson, G.R.; Hafkemeyer, L.M.; Handel, S.N. A long-term evaluation of applied nucleation as a strategy to facilitate forest restoration. Ecol. Appl. 2016, 26, 104-114. [CrossRef]

53. Strassburg, B.B.N.; Latawiec, A.E.; Barioni, L.G.; Nobre, C.A.; da Silva, V.P.; Valentim, J.F.; Vianna, M.; Assad, E.D. When enough should be enough: Improving the use of current agricultural lands could meet production demands and spare natural habitats in Brazil. Glob. Environ. Chang. 2014, 28, 84-97. [CrossRef] 
54. Harvey, C.A.; Villanueva, C.; Villacís, J.; Chacón, M.; Muñoz, D.; López, M.; Ibrahim, M.; Gómez, R.; Taylor, R.; Martinez, J.; et al. Contribution of live fences to the ecological integrity of agricultural landscapes. Agric. Ecosyst. Environ. 2005, 111, 200-230. [CrossRef]

55. Green, R.E.; Cornell, S.J.; Scharlemann, J.P.W.; Balmford, A. Farming and the fate of wild nature. Science 2005, 307, 550-555. [CrossRef]

56. Phalan, B.; Onial, M.; Balmford, A.; Green, R.E. Reconciling food production and biodiversity conservation: Land sharing and land sparing compared. Science 2011, 333, 1289-1291. [CrossRef]

57. Simo, A.; van der, M. Livelihood impacts of plantation forests on farmers in the greater mekong subregion: A systematic review of plantation forest models. Forests 2020, 11, 1-20.

58. Sherman, M.; Ford, J.; Llanos-Cuentas, A.; Valdivia, M.J.; Bussalleu, A. Vulnerability and adaptive capacity of community food systems in the Peruvian Amazon: A case study from Panaillo. Nat. Hazards 2015, 77, 2049-2079. [CrossRef]

59. Knoke, T.; Bendix, J.; Pohle, P.; Hamer, U.; Hildebrandt, P.; Roos, K.; Gerique, A.; Sandoval, M.L.; Breuer, L.; Tischer, A.; et al. Afforestation or intense pasturing improve the ecological and economic value of abandoned tropical farmlands. Nat. Commun. 2014, 5, 5612. [CrossRef] [PubMed]

60. Sattler, D.; Seliger, R.; Nehren, U.; de Torres, F.N.; da Silva, A.S.; Raedig, C.; Hissa, H.R.; Heinrich, J. Pasture Degradation in South East Brazil: Status, Drivers and Options for Sustainable Land Use Under Climate Change. In Climate Change Management; Springer: Cham, Switzerland, 2018; pp. 3-17. [CrossRef]

61. Wilmer, H.; Augustine, D.J.; Derner, J.D.; Fernández-Giménez, M.E.; Briske, D.D.; Roche, L.M.; Tate, K.W.; Miller, K.E. Diverse Management Strategies Produce Similar Ecological Outcomes on Ranches in Western Great Plains: Social-Ecological Assessment. Rangel. Ecol. Manag. 2018, 71, 626-636. [CrossRef]

62. Sánchez-Romero, R.; Balvanera, P.; Castillo, A.; Mora, F.; García-Barrios, L.E.; González-Esquivel, C.E. Management strategies, silvopastoral practices and socioecological drivers in traditional livestock systems in tropical dry forests: An integrated analysis. For. Ecol. Manag. 2021, 479, 118506. [CrossRef]

63. Bennett, N.J.; Roth, R.; Klain, S.C.; Chan, K.; Christie, P.; Clark, D.A.; Cullman, G.; Curran, D.; Durbin, T.J.; Epstein, G.; et al. Conservation social science: Understanding and integrating human dimensions to improve conservation. Biol. Conserv. 2017, 205, 93-108. [CrossRef]

64. Santos Martin, F.; van Noordwijk, M. Is native timber tree intercropping an economically feasible alternative for smallholder farmers in the Philippines? Aust. J. Agric. Resour. Econ. 2011, 55, 257-272. [CrossRef]

65. Knoke, T.; Calvas, B.; Moreno, S.O.; Onyekwelu, J.C.; Griess, V.C. Food production and climate protection-What abandoned lands can do to preserve natural forests. Glob. Environ. Chang. 2013, 23, 1064-1072. [CrossRef] 